\title{
ISTILAH-ISTILAH DALAM REGISTER PENGETAHUAN KELAUTAN NELAYAN MADURA DI DESA PESISIR, KECAMATAN BESUKI, KABUPATEN SITUBONDO: KAJIAN ANTROPOLINGUISTIK
}

\author{
THE TERMS OF THE MADURESE FISHERMAN MARINE KNOWLEDGE REGISTER \\ AT THE COASTAL VILLAGE, IN BESUKI SUB-DISTRICT, SITUBONDO DISTRICT: \\ ANTHROPOLINGUISTIC STUDY
}

\author{
Moch Abdur Rahman ${ }^{1}$, Kusnadi $^{2 *}$, Didik Suharijadi ${ }^{3}$ \\ ${ }^{1}$ Alumni Fakultas Ilmu Budaya, Universitas Jember \\ ${ }^{2,3}$ Fakultas Ilmu Budaya, Universitas Jember \\ *Corresponding Author: welfarestate@yahoo.co.id \\ Informasi Artikel:
}

Dikirim: 5/01/2019 ; Direvisi: 29/02/2019; Diterima: 15/03/2019

\begin{abstract}
Ecological factors, the close relationship between fishing communities and the sea (nature) has given rise to various types of marine knowledge in such a way, which is used as an adaptive function in "conquering and navigating the sea" as an effort to maintain the stability of the family's survival. A local knowledge system that has delivered a sociocultural pattern of fishing communities has distinctive cultural values, which are different from the various surrounding communities. The register of fishermen's marine knowledge is a variation of language based on the function of use and the context of its use that reflects social processes, and contains different meanings with the types of meanings in lexical dan grammatical. This study aims to describe the shape and meaning of registers of marine knowledge of Madurese fishermen using anthropolinguistic studies. The method used is descriptive qualitative. Research data in the form of terms and meanings on their cultural functions in marine registers. Efforts to extract data were carried out by participant observation methods and in-depth interviews, supplemented by written notes and recording aids in the form of a cellphone recorder. Data were analyzed using interactive data analysis (reduction, presentation, and withdrawal / verification of data) and interpretive methods oriented to the point of view of the community under study. In its realization, the terms in the register are searched for their lexical meanings using the referential equivalent method, which matches the lexicon meaning in the MaduraIndonesian dictionary. Next the cultural significance is determined based on the sociocultural function of the fishermen's interpretation The fishery knowledge register can be classified into four subsystems, including; register of fishermen's marine knowledge relating to; (1) current conditions; (2) weather / climate conditions; (3) conditions of the fishing area (fishing ground) and signs of fish presence; and (4) the techniques and fishing tools used.
\end{abstract}

Keywords: antrhopolinguistic, fisherman, local knowledge, register.

Abstrak

Faktor ekologis, kedekatan hubungan antara masyarakat nelayan dan laut (alam) telah melahirkan beragam jenis pengetahuan kelautan yang sedemikian rupa, yang digunakan sebagai fungsi adaptif dalam "menaklukkan dan mengarungi laut" sebagai upaya untuk 
menjaga stabilitas kelangsungan hidup keluarganya. Suatu sistem pengetahuan lokal yang telah mengantarkan corak sosial budaya masyarakat nelayan memiliki nilai budaya yang khas, yang berbeda dengan berbagai komunitas di sekitarnya. Register pengetahuan kelautan nelayan merupakan variasi bahasa berdasarkan fungsi penggunaan dan konteks dari penggunaannya yang mencerminkan proses sosial, dan mengandung makna yang berbeda dengan jenis makna leksikal dan gramatikal. Penelitian ini bertujuan mendeskripsikan bentuk dan makna register pengetahuan kelautan nelayan Madura dengan menggunakan kajian antropolinguistik. Metode yang digunakan adalah deskriptif kualitatif. Data penelitian berupa istilah-istilah dan makna pada fungsi kulturalnya dalam register kelautan. Upaya penggalian data dilakukan dengan metode pengamatan berperanserta dan wawancara mendalam, dilengkapi dengan catatan tertulis dan alat bantu rekam berupa recorder handphone. Data dianalisis dengan menggunakan analisis data interaktif (reduksi, penyajian, dan penarikan/verifikasi data) dan metode interpretif dengan berorientasi pada sudut pandang masyarakat nelayan. Dalam realisasinya, istilahistilah dalam register tersebut dicari makna leksikalnya dengan metode padan referensial, yakni memadankan dengan makna leksikon dalam kamus Bahasa Madura-Indonesia. Berikutnya ditentukan makna kultural berdasarkan fungsi sosiokultural dari interpretasi para nelayan. Hasil kajian menunjukkan bahwa register pengetahuan kelautan nelayan diklasifikasikan menjadi empat subsistem, yaitu; register pengetahuan kelautan nelayan yang berkaitan dengan (1) kondisi arus; (2) kondisi cuaca/iklim; (3) kondisi area penangkapan (fishing ground) dan tanda-tanda keberadaan ikan; serta (4) teknik dan alat tangkap yang digunakan.

Kata kunci: antropolinguistik, nelayan, pengetahuan lokal, register.

\section{PENDAHULUAN}

Budaya, yang secara sempit sebagai warisan leluhur merupakan salah satu alat transportasi manusia untuk menjangkau dan sekaligus membuktikan eksistensinya. Begitu pentingnya warisan budaya, UNESCO (United Nations Educational, Scientific and Cultural Organization) pada tahun 2003 menerbitkan konvensi yang mewajibkan dilakukannya pelestarian dan pengembangan terhadap warisan budaya yang tidak berwujud benda (Intangible Cultural Heritage) (Wikipedia.org). Salah satu alasan yang menjadi pertimbangan diterbitkannya konvensi tersebut adalah merosotnya kesadaran publik terhadap peran penting keberadaan warisan budaya yang tidak berwujud benda. Merosotnya perhatian tersebut memiliki sangkut-paut dengan perkembangan zaman (modernisasi) yang belakangan ini semakin glamor.

Perkembangan zaman (modernisasi) yang begitu pesat, tidak hanya menyebar pada kalangan masyarakat elit yang tinggal di perkotaan, tetapi juga telah menyebar dan bersentuhan langsung dengan kehidupan masyarakat lokal di pedesaan. Sentuhan yang terjadi secara terus-menerus, dikhawatirkan akan menggerus nilai-nilai kearifan lokal yang ada di dalam kehidupan masyarakat. Misalnya, studi kasus yang ditemukan di lapangan berupa adanya pengoperasian fish finder, yaitu alat pendeteksi ikan. Tidak menutup kemungkinan, kebiasaan baru ini akan memicu masyarakat nelayan (modern) untuk meninggalkan pengetahuan-pengetahuan lokal warisan dari leluhurnya, khususnya dalam memprediksi dan membaca tanda-tanda keberadaan ikan. Bagaimana suatu kelompok individu tertentu dapat dikatakan masyarakat nelayan (maritim) atau petani (agraris), jika identitas khas eksistensi masyarakatnya telah luntur? Oleh karena itu, penelitian mengenai register pengetahuan kelautan nelayan Madura di Desa Pesisir penting untuk dilakukan dalam rangka melestarikan 
nilai-nilai kearifan lokal yang ada di dalam kehidupan masyarakat nelayan di Desa Pesisir, Kecamatan Besuki, Kabupaten Situbondo agar tidak punah tergerus oleh zaman.

Register pengetahuan kelautan nelayan merupakan variasi bahasa berdasarkan fungsi penggunaan dan konteks dari penggunaannya yang mencerminkan proses sosial, mengandung makna yang berbeda dengan jenis makna leksikal dan gramatikal pada semantik leksikal. Secara mendasar dikatakan bahwa setiap tanda bahasa, termasuk istilah nama-nama pada budaya kelautan, memiliki makna (Saussure, 1964). Makna istilah-istilah budaya kelautan berkaitan erat dengan makna berdasarkan interpretasi masyarakat nelayan, yang disebut dengan makna kultural.

Penelitian ini bertujuan mendeskripsikan bentuk dan makna register pengetahuan kelautan nelayan Madura dengan menggunakan kajian antropolinguistik. Foley (1997), menyatakan bahwa linguistik antropologi (antropolinguistik) memandang bahasa melalui prisma konsep antropologi inti, yakni budaya. Linguistik antropologi (antropolinguistik) berusaha mencari "makna" (meaning) di balik penggunaan (use), kesalahan-penggunaan (misuse), dan ketidakpenggunaan (non-use) bahasa, baik bentuknya yang berbeda maupun variasi pemakaian (register) dan gayanya (style). Linguistik antropologi merupakan disiplin ilmu interpretatif yang mengupas bahasa secara mendalam untuk menemukan pemahamanpemahaman kultural (dalam Sibarani, 2015:6). Antropolinguistik dalam riset ini bertujuan mengkaji bahasa secara mendalam untuk menemukan pemahaman-pemahaman kultural masyarakat nelayan. Dalam kehidupan nelayan terdapat istilah-istilah yang spesifik terkait budaya kelautan, yakni(1) kondisi arus, (2) kondisi iklim (cuaca), (3) kondisi area penangkapan (fishing ground) dan tanda-tanda keberadaan ikan, dan (4) teknik dan alat tangkap yang digunakan. Semua bentuk istilah-istilah yang tergabung dalam register tersebut, masing-masing memiliki beberapa istilah yang bermakna. Terkait dengan makna, Saussure (1964) menyatakan bahwa terdapat hubungan antara tanda bahasa (sign language) dengan petanda (signifiant) dan penanda (signifier). Kata sebagai tanda atau satuan bahasa atau leksikon memiliki makna leksikal (Leech, 1981). Untuk mengetahui makna istilah-istilah yang terkait dengan budaya kelautan tidak lepas dari makna yang berasal dari pemahaman atau interpretasi masyarakat nelayan yang disebut sebagai makna kultural (Subroto, 2012) dan fungsi kulturalnya.

Menurut Halliday dan Hasan (1994:54) register dipahami sebagai konsep semantik yaitu sebagai susunan makna yang dikaitkan secara khusus dengan susunan situasi tertentu. Konsep situasi mengacu pada medan (field), pelibat (tenor), sarana (mode). Aktivitas sosial yang sedang terjadi atau pada saat tindakan berlangsung, apa sesungguhnya yang sedang dimaksudkan oleh para partisipan merupakan medan (field) yang perlu diperhatikan. Medan juga menyangkut pertanyaan-pertanyaan seperti; kapan, di mana, bagaimana, mengapa, dan sebagainya. Pelibat (tenor), menunjukan pada orang yang turut mengambil bagian, sifat, kedudukan atau status sosial, dan peran partisipan. Sarana (mode), merupakan dimensi cara, yakni mengacu pada cara terjadinya komunikasi, khususnya melalui lisan atau tulisan.

\section{METODE}

Menurut Afrizal (2015:11 - 12), metode penelitian adalah cara yang dilakukan peneliti untuk memecahkan masalah dan mencari jawaban atas pertanyaan-pertanyaan masalah penelitian, serta bagaimana cara peneliti mengumpulkan dan menganalisis data guna 
menjawab pertanyaan-pertanyaan dan mencapai tujuan-tujuan penelitian. Jenis penelitian ini adalah penelitian kualitatif. Menurut Bogdan dan Taylor (1975), penelitian kualitatif merupakan prosedur penelitian yang menghasilkan data deskriptif berupa kata-kata tertulis atau lisan dari orang-orang dan perilaku yang dapat diteliti.

Penelitian kualitatif adalah jenis pendekatan yang bersifat naturalistik, yang dalam mengungkap dan memahami suatu fenomena sosial dalam kehidupan masyarakat mengedepankan sudut pandang pelaku bahasa (natural). Dalam disiplin ilmu antropologi, pendekatan semacam ini disebut sudut pandang emik (emic view), yaitu suatu pendekatan yang berorientasi pada sudut pandang masyarakat yang diteliti. Penerapan pendekatan ini dilakukan untuk memperoleh pemaknaan dan berusaha memahami makna perilaku atau sosial budaya sesuai dengan perspektif para pelakunya.

Penelitian ini dilakukan di Desa Pesisir, Kecamatan Besuki Kabupaten Situbondo, Jawa Timur. Penyebutan Pesisir dikarenakan secara geografis terletak di kawasan transisi antara wilayah darat dan laut (Kusnadi, 2009:27). Sumber data berupa data primer dan data sekunder. Data primer diperoleh secara langsung dari subjek penelitian melalui dua metode, yaitu observasi terlibat dan wawancara mendalam, turut dilengkapi dengan catatan tertulis dan menggunakan alat bantu rekam berupa recorder handphone. Data primer berupa istilah-istilah dalam register kelautan yang dikumpulkan dari tiga kategori nelayan, yaitu nelayan pancing, nelayan sleret, dan nelayan jukung. Data sekunder diperoleh dari beberapa sumber, seperti jurnal, artikel ilmiah, makalah, dan halaman website tertentu yang memiliki korelasi dengan kebutuhan data penelitian. Data sekunder pada penelitian ini digunakan sebagai pendukung pemahaman, dan pembanding untuk memperjelas data primer. Data sekunder berupa; visualisasi atau ilustrasi-ilustrasi. Data dianalisis dengan menggunakan analisis data interaktif (reduksi, penyajian, dan penarikan/verifikasi data). Data yang berupa bentuk-bentuk istilah dalam budaya kelautan dianalisis dengan metode padan referensial (Sudaryanto, 2015) yakni dipadankan dengan makna leksikal yang terdapat dalam kamus bahasa Mudura, kemudian ditentukan makna yang sebenarnya berdasarkan interpretasi (Ricouer, 2015) dengan berorientasi pada sudut pandang masyarakat yang diteliti, yakni masyarakat nelayan untuk mengetahui makna kulturalnya (Subroto, 2012). Etnosains (Ahimsa Putra, 1985 ) digunakan untuk menelusuri pengetahuan yang khas, dalam kaitannya dengan pemahaman fungsi istilahistilah kelautan yang dimiliki secara kolektif oleh masyarakat nelayan Madura di Desa Pesisir, Kecamatan Besuki, Kabupaten Situbondo.

\section{HASIL DAN PEMBAHASAN}

Segala hal yang diterima oleh panca indera, baik itu yang bersifat konkret, abstrak, imajiner, bernilai maupun bebas nilai, dan positif maupun negatif, yang kemudian mengendap di dalam otak dan menjadi kesan di dalam pikiran merupakan hakikat dari pengetahuan manusia. Sebagai suatu sistem mata pencaharian di bidang kemaritiman, sudah barang tentu mata pencaharian nelayan memiliki sistem pengetahuan yang cukup mapan (established) dan mumpuni di bidang kelautan. Suatu sistem pengetahuan lokal (local knowleadge) mampu mengantarkan tatanan kehidupan masyarakat nelayan kepada suatu peradaban dan kebudayaan yang besar sebagai suatu sistem pengetahuan yang menjadi tonggak dalam mengarungi laut. 
Sebagai suatu kategori entitas kultural, budaya nelayan memenuhi tujuh unsur kebudayaan termasuk di dalamnya adalah bahasa, sistem pengetahuan, dan sistem mata pencaharian. Hubungan antara bahasa dan budaya merupakan dualitas yang nonotonom. Budaya mempengaruhi bahasa, dan bahasa adalah ekspresi linguistik yang mengemban makna kultural unsur-unsur kebudayaan. Bahasa merupakan alat transmisi kebudayaan yang diwariskan secara turun-temurun dari generasi ke generasi berikutnya. Dalam konteks ini, bahasa memiliki peranan penting dalam proses mempelajari dan mewariskan sistem pengetahuan kelautan kepada nelayan generasi berikutnya.

Berdasarkan substansinya, pengetahuan kelautan masyarakat nelayan di Desa Pesisir dapat dikelompokkan menjadi lima subsistem, yaitu pengetahuan kelautan yang berkaitan dengan; (1) kondisi arus, (2) kondisi iklim (cuaca), (3) kondisi area penangkapan (fishing ground) dan tanda-tanda keberadaan ikan, dan (4) teknik dan alat tangkap yang digunakan. Masing-masing subsistem pengetahuan kelautan tersebut melahirkan register bahasa yang berbeda-beda dan saling bertautan satu sama lain. Berikut uraiannya.

\section{Bentuk dan Makna Register Pengetahuan Kelautan Nelayan yang Berkaitan dengan Kondisi Arus}

Hasil penelitian dalam kutipan berikut merupakan penelitian yang dilakukan oleh Gene Ammarel (dalam Singgih, 2014:15-16), seorang Antropolog dari Ohio University, Amerika Serikat. Salah satu hasil penelitiannya yang menunjukkan pengetahuan para pelaut tradisional Mandar, adalah sebagai berikut:

“...Seiring diangkatnya sauh, saya bertanya ke arah manakah arus bergerak? Yang mengejutkan saya, Najamuddin tidak melihat ke laut yang dangkal dan berhias terumbu karang. Melainkan, seakan tertuntun secara refleks, matanya terangkat ke langit dan menyapukan pandangan dari cakrawala ke cakrawala lain, dia bertanya seperti sedang berpikir keras, "Bulan di mana?" Akhirnya diketahui, bulan berusia sembilan hari terbit pukul 10 pagi saat kami berangkat. Demi mengetahui bahwa air laut sedang surut, dia mencatat bahwa arus sedang mengalir ke barat..."

Seseorang yang berstatus sosial sebagai nelayan tidak terlepas dengan dunia laut. Salah satu faktor yang sangat penting untuk diperhatikan saat melaut adalah kondisi arus air laut. Dinamika kecepatan laju gelombang arus, arah angin yang sedang bertiup, serta posisi bulan di langit merupakan media alam yang digunakan untuk mengetahui kondisi arus. Dengan mengetahui kondisi arus dan arah angin secara tepat dapat membantu nelayan dalam memperoleh hasil tangkapan yang cukup melimpah. Pengetahuan akan kondisi arus juga menentukan berapa jam nelayan harus berada di tengah laut. Kemanakah arah perahu harus berlayar menerjang gelombang untuk menuju lokasi fishing ground. Kemudian, setelah sampai dilokasi fishing ground, di posisi manakah perahu harus diparkir atau dimanggar agar tidak berlawanan atau tidak terseret oleh arus. Semua kondisi ini ditentukan oleh sistem kognitif nelayan terkait dengan seberapa luas dan dalam pengetahuannya mengenai gejala alam yang berhubungan langsung dengan kondisi arus air laut. Jika tidak demikian, hasilnya sia-sia selama berada di tengah peraian luas. 
Untuk menyampaikan dan mentransmisikan sistem pengetahuan kelautan, nelayan membutuhkan bahasa sebagai wahana dalam mewariskan pengetahuannya terkait kondisi arus. Sehubungan dengan hal itu terbentuklah istilah-istilah lokal atau kosakata khusus yang digunakan oleh masyarakat nelayan untuk mempresentasikan kondisi arus. Istilah-istilah tersebut selain berfungsi sebagai alat untuk mempresentasikan kondisi arus air laut, juga berfungsi sebagai alat untuk memperkuat hubungan timbal balik antarsesama nelayan. Hal itu dikarenakan fitrah manusia sebagai makhluk sosial dalam memenuhi kebutuhan hidupnya masih membutuhkan campur tangan, jasa, dan pikiran/inspirasi dari orang lain. Kosakata khusus tersebut, kemudian menjadi pengetahuan kolektif masyarakat yang berstatus sosial sebagai nelayan. Suatu kosakata khusus yang digunakan atas dasar kepentingan dan pusat perhatian yang sama dalam kelompok masyarakat, lazim disebut sebagai register (Chaer dan Agustina, 2010:70-71). Adapun istilah-istilah dalam Register Pengetahuan Kelautan Nelayan yang Berkaitan dengan Kondisi Arus meliputi: Terkas dan Bâdâ'ân. Berikut uraiannya.

\section{a) Terkas}

Istilah terkas [tərkas] merupakan bentuk kata yang monomorfemis, yaitu bentuk gramatikal yang terdiri atas satu morfem (morfem tunggal) (Chaer, 2007:183). Kata terkas [tərkas] dalam Kamus Lengkap Bahasa Madura Indonesia memiliki arti leksikal 'langsung' (Pawitra, 2009:496). Dalam interaksi sosial masyarakat nelayan, kata terkas merupakan istilah yang secara kultural digunakan oleh nelayan untuk menggambarkan kondisi arus yang bagus dan baik untuk menangkap ikan. Secara semantik, kata terkas mengalami perluasan makna, yaitu makna yang terkandung pada sebuah kata lebih luas dari yang dipertimbangkan (Pateda, 2001:120).

Berdasarkan pengetahuan kelautan nelayan, arus air laut terbagi atas dua bagian yaitu, arus atas dalam bahasa lokal disebut aros ettas [aros əttas] dan arus bawah dalam istilah lokal disebut aros bâbâ [aros bəbə]. Arus atas adalah arus yang mengalir di permukaan air laut atau lebih sering dikenal dengan sebutan gelombang ombak. Arus bawah adalah arus yang mengalir di kedalaman dasar laut. Keadaan atau gerak kedua arus ini sangat berpengaruh terhadap keadaan biota laut itu sendiri, misalnya ikan, kepiting, udang dan sebagainya yang juga sangat menentukan terhadap hasil tangkapan nelayan. Keadaan arus atas dan arus bawah ini sangat erat kaitannya dengan fenomena pasang surut air laut.

Secara kultural, pengetahuan mengenai kondisi arus terkas tersebut diwariskan secara turun temurun, yaitu dengan cara mengajarkannya melalui praktek secara langsung di laut. Parameter arus yang bagus ditunjukkan dengan arus atas dan arus bawah yang hidup. Untuk mendeteksi arus sedang hidup (bagus) atau tidak, biasanya nelayan melakukan uji coba arus dengan cara mengulur senar yang diikatkan timah atau pemberat hingga ke dasar laut. Kondisi arus yang bagus ditunjukkan oleh senar yang tidak dalam keadaan vertikal atau tegak lurus. Logikanya, semakin besar tekanan gelombang arus air laut yang mengalir, maka semakin besar pula kemungkinan benda-benda (bebatuan) di dalamnya untuk berpindah dari posisi semula (terhanyut). Jika kondisi arus di kedalaman laut itu besar, timah pemberat akan turut terhanyut sesuai arah arus mengalir.

Indikasi lain yang menunjukkan bahwa arus sedang bagus adalah selera pola makan ikan yang rakus. Laju arus yang deras di dasar laut akan memicu ikan untuk bergerak lebih 
Istilah-istilah dalam Register Pengetahuan Kelautan Nelayan Madura di Desa Pesisir, Kecamatan Besuki, Kabupaten Situbondo: Kajian Antropolinguistik (Moch Abdur Rahman, Kusnadi, Didik Suharijadi)

aktif. Ketika ikan bergerak aktif di kedalaman peraian laut, memungkinkan ikan untuk bergerak lebih aktif pula dalam mencari makanannya. Oleh karena itu, kondisi arus yang bagus merupakan peluang besar bagi nelayan untuk mendapatkan hasil tangkapan yang lebih banyak. Sederhananya, jam makan ikan atau waktu yang memicu ikan lebih aktif mencari makan ditentukan oleh kondisi arus di dasar kedalaman laut. Pengetahuan ini sangat penting untuk diketahui oleh nelayan, khususnya oleh nelayan muda.

\section{b) Bâdâ'ân}

Istilah bâdâ'ân [bə⿳亠口ə?ən] merupakan kata yang berbentuk polimorfemis, yakni kata yang terdiri atas dua morfem atau lebih), karena telah mengalami proses morfologis afiksasi (pengimbuhan) (Chaer, 2007:177-185). Kata bâdâ'ân berasal dari bentuk dasar bâdâ [bəḍ] berarti 'ada' (Pawitra, 2009:12). Dalam penggunaannya mengalami proses afiksasi atau pengimbuhan berupa sufiks atau akhiran \{-ən\} menjadi bâdâ'ân (Sofyan, 2016:141). Setelah mengalami proses afiksasi istilah bâdâ'ân mempunyai arti 'lumayan ada atau cukup banyak'. Berdasarkan makna dalam fungsi kulturalnya, istilah ini digunakan oleh nelayan untuk menyatakan kuantitas ikan laut yang jumlahnya tidak terlalu banyak, atau ikan itu ada tapi tidak banyak. Secara semantik, kata bâdâ'ân mengalami perluasaan makna, yaitu makna yang terkandung pada sebuah kata lebih luas dari yang dipertimbangkan (Pateda, 2001:120).

Berdasarkan pengetahuan kelautan nelayan, jumlah atau kuantitas ikan di perairan laut sangatlah potensial. Namun, pada kondisi tertentu ikan-ikan tersebut tidak banyak untuk ditangkap. Hal itu disebabkan oleh berbagai faktor antara lain, cuaca atau iklim, kondisi arus, dan fase bulan. Ketika terjadi badai, kondisi tersebut sangat tidak memungkinkan nelayan untuk melanjutkan melakukan aktivitas penangkapan karena resiko yang harus diterima sangtlah besar. Oleh karena itu, nelayan harus mencari tempat berlindung pada pantai terdekat untuk berlabuh sementara waktu. Badai berlangsung biasanya disertai pula oleh gelombang ombak yang tinggi. Gelombang ombak yang tinggi dapat memicu ikan untuk mencari tempat berlindung dari derasnya arus air laut, khususnya jenis ikan karang.

Walaupun tidak sedang terjadi badai, arus yang mengalir terlalu kecil atau lamban dapat menyebabkan potensi ikan tidak terlalu banyak. Arus yang mengalir kecil ini terjadi ketika pasang surut kecil atau fase bulan sabit tua. Pada fase bulan sabit, fenomena pasang surut air laut kecil berpengaruh terhadap aliran arus yang mengalir di kedalaman perairan laut menjadi lamban. Arus yang mengalir lamban ini meyebabkan ikan tidak terlalu aktif mencari makanan atau selera makan ikan menurun. Meski demikian, ikan tetap ada atau nelayan tetap dapat memperoleh hasil tangkapan, namun tidak banyak.

Secara sosiokultural, pada saat ikan ada namun tidak terlalu banyak tersebut, nelayan memiliki alternatif lain untuk menunjang hasil tangkapannya. Alternatif itu dilakukan dengan cara berpindah-pindah tempat penangkapan dari rumpon yang satu ke rumpon lain. Aktivitas berpindah-pindah area penangkapan tersebut oleh nelayan diungkapkan dengan istilah rèhnyarèh [r€-ñareh] atau proses mencari-cari, yaitu aktivitas mencari-cari ikan antarberberapa fishing ground. Proses mencari-cari ini menunjukkan betapa gigih, giat, dan pantang menyerah dari sifat masyarakat nelayan. Sifat gigih, giat, dan pantang menyerah ini dibentuk oleh adanya suatu harapan. Dalam hal ini, laut dalam persepsi nelayan merupakan satusatunya harapan yang menjadi titik tumpu atau penopang kehidupannya. 


\section{Bentuk dan Makna Register Pengetahuan Kelautan Nelayan yang Berkaitan dengan Kondisi Iklim/Cuaca}

Refleksi peredaran bumi mengelilingi matahari adalah perubahan kedudukan tahunan matahari di langit, yang menimbulkan pola perubahan musim tahunan. Fenomena regulasi (periodik) tahunan akibat perubahan kedudukan matahari tersebut menyebabkan perubahan musim di belahan bumi Utara dan belahan bumi Selatan, dari musim panas, gugur, dingin, semi, panas lagi, atau perubahan musim di Indonesia dari musim penghujan ke musim kemarau. Berdasarkan keteraturan pengulangan kedudukan matahari yang selama ribuan tahun, manusia menghafalkan pola musim, iklim, dan fenomena alam lainnya. Nenek moyang kita pun juga membuat kalender tahunan bukan saja berdasarkan kalender Syamsiah (Masehi) atau kalender Komariah (Hijrah/lslam), tetapi juga berdasarkan kejadian-kejadian alam, seperti musim penghujan, kemarau, musim berbunga, dan letak dan waktu kemunculan gugus bintang rasi tertentu, serta pengaruh fase bulan terhadap pasang surut air laut.

Datang dan perginya musim tidak jatuh persis pada tanggal dan bulan yang sama setiap tahunnya. Namun, para nelayan dapat membaca, mendeteksi, dan memprediksi tandatanda musim dengan melihat langit sebagai cara bertahan hidup dalam menghadapi tantangan alam. Musim bisa bergeser dari bulan-bulan tertentu, tetapi hewan dan tumbuhan akan tetap berperilaku karena pengaruh faktor-faktor yang sama: cuaca, suhu, kelembaban, pencahayaan matahari, dan iklim yang sifatnya lebih luas dari musim. Flora dan fauna akan tetap merespon dan berperilaku sesuai dengan alam lingkungan yang secara konstan dapat mempengaruhinya. Tampilan-tampilan itu nenek moyang pahami selaras dengan apa yang mereka lihat pada posisi penampakan gugus rasi bintang tertentu di langit malam atau saat menjelang malam. Bintang-bintang telah menjadi bagian dari setiap kebudayaan para nelayan.

Bagi nelayan tradisional, untuk mengetahui keadaan atau perubahan cuaca digunakan petanda dan gejala alam, misalnya kemunculan dan letak rasi bintang tertentu, arah dan sifat angin, kilatan cahaya di langit, dan suara guntur di beberapa penjuru arah mata angin. Pengetahuan gejala alam tersebut sangat penting untuk diketahui karena dengan pengetahuan dan pengalaman yang tepat, para nelayan akan dapat betindak dengan tepat pula, sehingga saat melaut, nelayan bisa membuahkan hasil tangkapan yang banyak dan terhindar dari berbagai bencana alam. Kemampuan nelayan dalam membaca dan menganalisis petanda dan gejala alam, juga dapat membantu nelayan dalam memprediksikan keadaan yang akan terjadi misalnya, waktu musim ikan atau sebaliknya paceklik ikan, musim ombak besar, dan musim angin. Adapun istilah-istilah dalam register pengetahuan kelautan nelayan yang berkaitan dengan kondisi iklim/cuaca adalah Lèntang Kartèkah dan Ghâludhughân. Berikut uraiannya.

\section{a) Lèntang Kartèkah}

Istilah lèntang kartèkah [lentay kartekah] merupakan bentuk frasa sebagai gabungan dari bentuk dasar lèntang [lentay] berarti 'bintang' (Pawitra, 2009:264), dan bentuk dasar kartèkah [kartєkah] berasal berarti 'kumpulan atau kelompok'. Dalam Kamus Lengkap Bahasa Madura Indonesia (Pawitra, 2009), tidak dijumpai arti dari kata kartèkah. Secara etimologi, kata kartèkah merupakan padanan dari kata kertèh [kərt€h], yang memiliki arti 'kumpulan orang berias diri'. Berdasarkan penggunaannya, secara kultural istilah lèntang kartèkah digunakan untuk memberi nama gugusan bintang yang letaknya secara 
berkelompok. Menurut beberapa sumber, diberi nama lèntang kartèkah karena kemunculan bintang tersebut secara berkelompok sehingga saat dipandang tampak indah. Secara gramatis, lèntang kartèkah berbentuk frase adjektiv, yaitu kelompok kata yang dibentuk dengan kata sifat atau kata keadaan sebagai inti (diterangkan) dengan menambahkan kata lain yang berfungsi menerangkan (Ramlan, 2005:152). Secara semantik, kata lèntang kartèkah memiliki makna khusus, yaitu makna yang tetap dan pasti yang peggunaannya hanya terdapat pada bidang kegiatan atau keilmuan tertentu (Pateda, 2001:106).

Berdasarkan pengetahuan kelautan nelayan, kemunculan rasi bintang menjadi tetenger [tətəyər] atau pedoman nelayan bahwa akan segera musim ikan. Lèntang kartèkah biasanya akan muncul setelah berakhirnya musim barat. Diperkirakan pada pertengahan bulan Maret atau bulan Maret akhir, jenis rasi bintang lèntang kartèkah ini akan muncul di langit bagian Timur. Apabila kemunculan lèntang kartèkah disertai dengan pancaran cahaya yang sangat terang atau terang benderang, tanda tersebut merupakan simbol atau kode alam yang mengisyaratkan bahwa musim ikan laut akan melimpah. Sebaliknya, apabila kemunculan rasi lèntang kartèkah ini disertai dengan pancaran cahaya yang redup atau remang-remang, berdasarkan pengalaman nelayan sudah dipastikan hasil tangkapan saat melaut tidak begitu banyak.

Kemampuan dalam hal membaca dan memprediksi gejala alam tersebut di atas masih dipegang teguh oleh masyarakat nelayan yang berstatus sosial sebagai nelayan pancing. Di Dusun Mandaran, Desa Pesisir, Kecamtan Besuki, mayoritas masyarakatnya berprofesi sebagai nelayan tradisional (nelayan pancing). Berdasarkan pengakuan beberapa informan, secara kultural jika lèntang kartèkah muncul disertai pancaran cahaya yang terang benderang, secara serentak dan kompak seluruh nelayan akan mempersiapkan alat tangkapnya. Alat tangkap tersebut disebut planjhâr [planjhar], yaitu alat pancing yang terdiri atas satu mata kail berukuran besar, yang biasa digunakan oleh nelayan untuk menangkap ikan berukuran besar. Kemunculan lèntang kartèkah ini, menurut pengalaman nelayan merupakan isyarat atau tanda bahwa akan terjadi musim ikan berukuran besar, seperti: ikan marlin, tuna, tengiri, kemudian jenis ikan karang seperti kerapu, kakap merah, kakap putih, ikan putihan, dan berbagai jenis ikan berukuran besar lainnya.

Menurut Rabidin (62 tahun), jika lèntang kartèkah telah muncul di langit bagian Timur, antarsesama nelayan akan saling mengingatkan satu sama lain. Peringatan itu diwujudkan dalam bentuk kalimat berupa pemberitahuan, seruan atau berbentuk ungkapan metaforis. Salah satu bunyi ungkapan tersebut sebagai berikut.

"Wa mettonah lèntang kartèkah satèyah kana'! Pasekken atomah, sè alos kasarèn! Paghârre pancèngah, sè kenè rajâin!”.

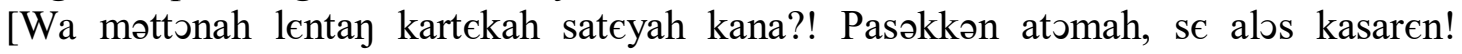
Pagharro pancenah, se ken€? rajain!].

Artinya, 'itu dia bintang kartèkah sekarang telah keluar kawan! Senar pancingnya dikuatkan, yang berukuran kecil supaya diganti yang lebih besar! Gunakan kail yang kuat, kail yang kecil supaya diganti yang lebih besar!' (Wawancara, 12 September 2018). 
Jika dianalisis lebih lanjut, ungkapan ini mengandung atau menyimpan pengetahuan kolektif masyarakat nelayan tentang gejala alam dan keadaan selanjutnya yang akan dihadapi. Motif dari ungkapan ini, yaitu memberi tahu bahwa rasi bintang yang ditunggu-tunggu telah muncul. Tanpa penjelasan lebih lanjut, masing-masing nelayan telah mengetahui makna dan maksud dari bentuk kalimat seruan atau ungkapan metaforis tersebut. Yang setiap nelayan telah mengetahui persis bahwa kemunculan lèntang kartèkah merupakan isyarat musim ikan besar.

\section{b) Ghâludhughân}

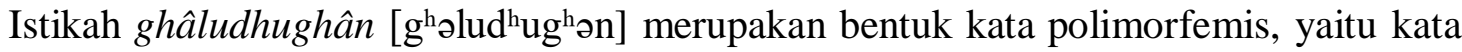
yang telah mengalami proses morfologis, seperti; afiksasi (pengimbuhan), reduplikasi (pengulanagn) dan komposisi atau pemajemukan (Chaer, 2007:177-185). Kata ghâludhughân berasal dari bentuk dasar ghâludhug [gh əlud $^{\mathrm{h}} \mathrm{Ug}$ ] berarti 'guntur, atau suara yang ditimbulkan oleh kilat atau petir' (Pawitra, 2009:193). Dalam penggunaannya mengalami proses afiksasi atau pengimbuhan berupa sufiks atau akhiran \{-ən\} menjadi ghâludhughân (Sofyan, 2016:141). Setelah mengalami proses afiksasi, kata ghâludhughân mempunyai arti 'bunyi yang menggema di langit yang ditimbulkan oleh kilat atau petir yang terjadi secara berulang-ulang'. Berdasarkan penggunaannya, secara kultural kata ghâludhughân digunakan oleh nelayan untuk menyatakan kondisi cuaca yang tidak baik untuk melaut. Secara semantik, kata ghâludhughân mengalami perluasaan makna, yaitu makna yang terkandung pada sebuah kata lebih luas dari yang dipertimbangkan (Pateda, 2001:120).

Secara umum diketahui bahwa ghâludhughân (suara guntur) hanya terjadi ketika akan menjelang musim penghujan, atau ketika musim hujan berlangsung. Berdasarkan pengetahuan nelayan, kehadiran dan berakhirnya musim barat disambut oleh suara guntur dari empat penjuru arah mata angin, yaitu arah Tenggara, Barat Daya, Barat Laut, dan Timur Laut. Indikasi bahwa musim barat atau musim penghujan akan segera tiba ditandai oleh suara guntur yang terdengar berulang-ulang dari arah tèmor lao' [tєmor la ?] atau Tenggara. Suara guntur dari arah Tenggara tersebut oleh nelayan dianggap sebagai peringatan agar segera mempersiapkan perlengkapan keamanan perahunya. Ketika musim barat telah tiba, biasanya disertai oleh curah hujan tinggi, gelombang ombak beringas, dan laju angin kencang. Musim barat merupakan musim paceklik bagi nelayan. Kondisi ini berlangsung kurang lebih selama 1 bulan.

Isyarat berikutnya, apabila ghâludhughân atau suara guntur terdengar berulang dari arah barat daya, menurut nelayan merupakan isyarat atau tanda bahwa sebentar lagi keadaan laut akan kembali normal/stabil, dan bisa digunakan untuk melaut. Walaupun saat itu kondisi alam tetap menghadapi musim hujan, namun kondisi ombak, dan angin mulai bersahabat. Suara guntur di arah Barat Daya ini pula menjadi indikasi bahwa ikan di laut sudah bisa ditangkap, dan kemungkinan besar semua jenis ikan atau biota laut akan melimpah. Pada saat musim ikan tiba, kendala yang dihadapi oleh nelayan adalah penurunan harga jual ikan.

Apabila ghâludhughân atau suara guntur terdengar berulang dari arah Barat Laut, menurut pengetahuan nelayan, hal itu merupakan indikasi bahwa dalam waktu dekat musim hujan akan segera berakhir. Persentanse curah hujan yang semula tinggi mulai berkurang. Kondisi alam tetap dalam masa/musim hujan, namun curah hujan telah berkurang. Musim 
hujan akan berakhir ditandai oleh adanya suara guntur yang terdengar dari arah Timur Laut. Dalam presepsi nelayan, suara guntur yang terdengar dari arah Timur Laut merupakan wujud perilaku alam yang sedang berpamitan. Dalam hal ini, nelayan menganggap bahwa alam juga memiliki sistem normatif alamiah, yaitu pola perilaku alam yang teratur, berkesinambungan, dan terstruktur. Kearifan lokal dalam hal membaca gejala alam semacam ini telah diwariskan secara turun-temurun.

\section{Register Pengetahuan Kelautan Nelayan Berdasarkan Kondisi Area Penangkapan (Fishing Ground) dan Tanda-tanda Keberadaan Ikan}

Wilayah laut dalam pandangan nelayan pesisir dipandang sebagai kawasan terbuka dan bebas kelola. Tidak ada suatu wilayah laut yang merupakan kepemilikan pribadi atau kelompok, kecuali daerah rumpon dan lokasi penanaman rumput laut. Selain itu, laut dipandang pula sebagai sumber dari segala aktivitas pencaharian hidup. Pandangan semacam ini merupakan persepsi masyarakat yang telah dianut secara umum oleh seluruh masyarakat nelayan pesisir. Oleh karena itu, masyarakat nelayan pesisir telah memiliki pengetahuan yang dapat memprediksikan beberapa lokasi/wilayah (fishing ground) yang diketahui terdapat banyak ikan dan biota laut lainnya. Seperti diketahui bahwa ketika mereka melihat suatu lokasi yang dangkal di area terumbu karang dan dasar berpasir, berlumpur atau berbatu-batu, di situ terdapat biota laut spesies yang tidak liar (relatif diam).

Hal lain yang menarik adalah sistem kognitif mereka yang memiliki akurasi daya ingat yang kuat, terutama dalam hal mengingat lokasi daerah penangkapan atau fishing ground. Sebagaimana yang kita ketahui bahwa laut yang demikian luas itu tidak menjadikan pelaut bangsa kita kebingungan saat dihadapkan pada salah satu fishing ground tertentu. Hal itu menjadi bukti konkrit bahwa pelaut bangsa kita adalah seorang penjelajah laut yang handal, mumpuni, dan mapan (established). Untuk menciptakan daya ingat yang akurat tersebut membutuhkan waktu berproses yang panjang, wawasan yang luas, dan pengalaman yang terlatih.

Sebagaimana yang di ungkapkan oleh Soejono (63 tahun).

"Biasanya yang menjadi patokan atau tanda itu adalah lampu dan gunung. Kalau siang hari itu menandai-nya pakai gunung. Gunung itu kan ada lekukannya. Kemudian, saya tandai lekukan yang nomer berapa, model lekukan gunungnya seperti apa, dan selanjutnya, saya akan menarik garis lurus antara selatan, barat, timur, dan utara. Misalkan posisi gunung itu ada di utara dan selatan, maka kalau ditarik garis lurus ke arah barat tepatnya lurus dengan apa, kemudian kalau ditarik lurus ke timur lurus dengan apa. Cara itu harus betul-betul diingat dan di perhatikan secara teliti kondisi lingkungan sekitar fishing ground. Dan kalau malam hari saya menggunakan lampu-lampu daratan yang paling terang. Biasanya yang sering saya gunakan sebagai tanda; lampu mercusuar, lampu tower sinyal, dan lampu tambak. Jadi, patokannya adalah topografi darat dengan memaanfaatkan lampu dan gunung sebagai tanda (tetenger). Dan masing-masing spot (fishing ground) memiliki tanda atau patokan (tetenger) yang berbeda-beda. Tujuannya untuk mengingat secara tepat lokasi fishing ground. Kalau daya ingat terhadap topografi darat yang dijadikan tetenger itu lemah, sangat berpengaruh terhadap hasil tangkapan. Misalnya kemarin itu nangkapnya di wilayah topongan, kemudian besoknya balik lagi, tapi lupa atau posisinya tidak tepat 
sasaran, maka hasilnya bisa sedikit. Soalnya, geser sedikit saja dari posisi penangkapan yang ditempati kemarin (sebelumnya), ikan itu sudah tidak mau makan. Bukan berarti tidak ada ikannya. Oleh karena itu, akurasi daya ingat nelayan harus kuat mengenai tanda-tanda yang dijadikan sebagai patokan (tetenger). Sebab tidak semua area lautan yang begitu luasnya itu ada ikannya. Jadi, memang ada titik-titik atau spot-spot tertentu yang merupakan tempat ikan itu berkumpul" (Wawancara, 12 September 2018).

Menurut pengetahuan kelautan nelayan, terumbu karang merupakan sebagai tempat tinggal, tempat mencari makan, tempat bertelur dan juga tempat berlindung bagi ikan, seperti "rumah" bagi manusia. Di sekitar karang tersebut hidup berbagai jenis spesies ikan yang dalam bahasa lokal disebut jhuko' bâbâ [jh ukə? bəbə] atau ikan bawah. Salah satu ruang atau tempat yang dimanfaatkan oleh nelayan dalam menangkap ikan adalah lokasi terumbu karang (fishing ground). Nelayan Pesisir menyebutnya daerah itu bhungkanah karang [ $\mathrm{b}^{\mathrm{h}} \mathrm{u}$ kanah karay] atau gugusan terumbu karang. Bagi nelayan Pesisir bhungkanah karang dianggap sebagai suatu kumpulan terumbu karang yang merupakan tempat hidup atau sarang spesies ikan-ikan karang. Menurut pandangan nelayan, kawasan terumbu karang yang di dalamnya terdapat sarang ikan yang dijadikan sebagai lokasi penangkapan (fishing ground), harus dipelihara dan dijaga. Pandangan demikian, membuat nelayan pesisir mengenal alat pancing dan sejenisnya, yang dinilai sebagai alat tangkap yang ramah lingkungan.

Setiap gugusan karang memiliki bentuk dan luas yang berbeda-beda, dan di dalamnya biasanya terdapat beberapa rumah/sarang ikan. Gugusan karang tersebut, merupakan lahan potensial bagi spesies ikan dan biota laut lainnya untuk berkembang biak terutama pada kedalaman antara minimal 5 meter, dengan jarak 3 sampai 5 mil dari bibir pantai. Berkenaan dengan itu pula masyarakat nelayan memberi nama pada gugusan karang sesuai dengan nama tertentu dalam bahasa Madura, karena erat kaitannya dengan nama yang diwariskan oleh nenek moyang mereka. Sejak dahulu, wilayah penangkapan atau fishing ground dianggap sebagai warisan tempat milik nenek moyangnya dalam memanfaatkan sumberdaya hayati laut. Namun demikian, gugusan karang tersebut dapat pula dimanfaatkan oleh orang lain di luar masyarakat pesisir untuk mencari rezeki dalam rangka memenuhi kebutuhan dan tanggung jawab hidupnya.

Dari berbagai gugusan karang tersebut di atas menurut informasi nelayan Pesisir, bahwa gugusan karang yang kaya akan keanekaragaman hayati laut dan selalu didatangi oleh

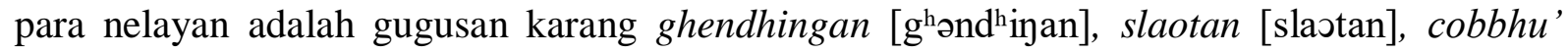
[çbb ${ }^{\mathrm{h}} \mathrm{u}$ ?], dan jhân abuh [jhan abuh]. Beberapa gugusan karang tersebut merupakan tempat yang potensial, dimana banyak spesies ikan berukuran besar, seperti ikan tenggiri, ikan putihan, paus, kerapu, kakap, marlin, dan ikan tombhuk [tวmb ${ }^{\mathrm{h} u k]}$ atau lemadang. Sehubungan dengan itu, masyarakat nelayan juga memiliki pengetahuan tentang kawasan di dasar laut yang berlumpur, dan berpasir. Dasar laut yang berlumpur atau lumpur bercampur pasir biasanya dijadikan tempat untuk membuat sarang oleh jenis biota laut, seperti sejenis udang dan kepiting. Dalam istilah lokal, sarang atau tempat tinggal udang dan kepiting disebut onto' [ontว?].

Hal unik lainnya, masyarakat nelayan Pesisir juga mengenal dan memperaktekkan pembuatan sarang ikan. Sarang buatan ini terbentuk karena ada campur tangan nelayan, yang memang sengaja disediakan untuk memudahkan aktivitas penangkapan. Dalam istilah lokal, 
nelayan mengenal dua jenis sarang buatan, yaitu angghâs [ang ${ }^{\text {has}] ~ d a n ~ o n j h e m ~[э n j ~}{ }^{\text {hom] }}$ berarti 'rumpon'. Angghâs merupakan sarang ikan yang disediakan oleh nelayan untuk spesies ikan berukuran besar, baik jenis ikan karang (kerapu, kakap, kurisi, teribang, dsb.) maupun ikan atas (tenggiri, marlin, tuna, lemadang, dsb.). Berbeda dengan angghâs, onjhem adalah sarang ikan yang disediakan untuk spesies ikan atas berukuran kecil, seperti; layang, tongkol, lemuru, kembung, teri, dan sebagainya.

Berkenaan dengan hal tersebut di atas, bukan berarti masyarakat nelayan Pesisir tidak mengetahui sarang alami spesies ikan atas. Sama halnya dengan spesies ikan bawah atau ikan karang, sarang alaminya berupa gugusan karang. Untuk sarang alami jenis ikan atas, dalam istilah lokal oleh nelayan disebut tajhung [tajhuy] yang berarti 'tanjung'. Tajhung adalah pertemuan antara mulut muara sungai dengan permukaan laut. Menurut pengetahuan nelayan, pertemuan antara mulut muara dengan permukaan laut ini membentuk sebuah lubang besar (seperti sumur) yang merupakan sarang alami spesies ikan atas. Biasanya di kawasan tajhung tersebut dominan didapati spesies ikan berukuran kecil seperti; ikan teri, ikan dhuk-dhuk [d ${ }^{\text {h }}$ uk-d ${ }^{\text {h }} \mathrm{uk}$ ], bulus [bulus], kembung, dan sebagainya.

Masyarakat nelayan memiliki pengetahuan tentang keberadaan adanya ikan pada suatu tempat tertentu dengan cara melihat tanda-tanda yang ada, antara lain: Jhuko' ngeddhâp [jhko? yəddhap], yaitu adanya kilatan cahaya ikan seperti memutih yang kelihatan dari kedalaman air laut atau kejauhan terutama pada malam hari. Kompolnah manu' [kompslnah manu?], yaitu tampak dari kejauhan terutama pada siang hari, dengan adanya kumpulan burung pemangsa ikan, baik itu yang berwarna putih (burung pelikan) maupun berwarna hitam (burung kormoran). Jhuko' amain [jh uks? amain], yaitu adanya ikan-ikan yang bermunculan dan berlompat-lompat ketika mencari makanan di permukaan air laut terutama pada pagi hingga sore hari. Jhuko' nyabâ'ân [jh uko? ñabə?ən], yaitu adanya gelembunggelembung air yang muncul ke permukaan dan terjadinya pula perubahan warna air laut.

\section{Register Pengetahuan Kelautan Nelayan Berdasarkan Alat dan Teknik Penangkapan}

Salah satu hal penting dalam kehidupan nelayan adalah teknologi penangkapan, baik dalam bentuk alat tangkap maupun berupa alat bantu penangkapan (perahu). Pentingnya pengetahuan tentang penguasaan teknologi tangkap sangat diperlukan untuk menopang kebutuhan aktivitas tangkap pada saat melaut. Aktivitas penangkapan belum sepenuhnya dapat berjalan lancar apabila tidak dilengkapi piranti penangkapan yang tepat sesuai dengan jenis ikan target. Keuntungan yang melimpah bukan bergantung pada rejeki semata, melainkan pula faktor alat tangkap yang digunakan sangat memiliki peranan penting demi kelancaran aktivitas penangkapan.

Pada umumnya, struktur sosial masyarakat nelayan di Desa Pesisir terbagi menjadi tiga kategori sosial berdasarkan jenis alat dan teknologi tangkap yang digunakan, di antaranya; nelayan sleret (modern), nelayan jaring (semi modern), dan nelayan pancing (tradisional). Nelayan sleret tergolong ke dalam nelayan modern, karena dalam aktivitas penangkapannya telah mengenal dan mengaplikasikan teknologi tangkap berupa GPS, dan fish finder atau alat pendeteksi ikan. Alat tangkap inti berupa payang, yaitu jaring lingkar atau purse seine. Dalam istilah lokal disebut pajâng [pajay]. Pengoperasiannya dengan cara menghadang arah renang ikan. 
Nelayan jaring merupakan sebutan lokal bagi nelayan udang. Dalam istilah lokal alat

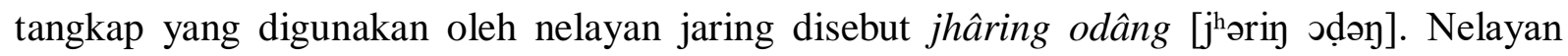
jaring tergolong ke dalam nelayan semi modern, karena dalam aktivitas penangkapannya menggunakan gill nets atau jaring insang. Pengoperasiannya yaitu menghadang arah gerak udang atau ikan, yang kemudian ketika menabrak jaring, kepala udang atau insang ikan langsung terjerat dan tidak dapat meloloskan diri.

Nelayan pancing merupakan jenis nelayan tradisional. Alat tangkap utama nelayan pancing berupa handline, yaitu alat pancing yang dioperasikan secara langsung dengan mengandalkan kekuatan tangan. Berdasarkan pengetahuan nelayan, alat pancing handline dikelompokkan menjadi tiga jenis, yaitu; alat pancing ancèt [ancєt], planjhâr [planjh ${ }^{\mathrm{h}}$ ], dan krèkèt [krєkєt].

Sehubungan dengan hal tersebut di atas, masyarakat nelayan di Desa Pesisir memperaktekan adanya kepercayaan terhadap hal-hal yang berunsur magis. Kepercayaan tersebut oleh sebagian besar masyarakat nelayan dianggap relevan dan korelatif dengan aktivitas keseharian mereka sebagai warisan dari leluhur masyarakat nelayan. Adanya kepercayaan terhadap kalanceng potè [kalancəy pote] diyakini dapat mendatangkan rejeki. Penentuan hitungan hari dan pasaran yang baik dalam membuat atau memperbaiki alat tangkap. Menyiramkan air pada perahu, dan membakar kemenyan sebelum berangkat melaut merupakan simbol harapan nelayan supaya bisa pulang dari melaut dengan selamat dan dapat membuahkan hasil tangkapan. Wujud kebudayaan ini telah mengakar dan menjamur dalam kehidupan sosial masyarakat nelayan.

\section{SIMPULAN}

Berdasarkan hasil penelitian dan pembahasan rumusan masalah yang telah diuraikan, dapat disimpulkan bahwa register pengetahuan kelautan nelayan Madura di Desa Pesisir, Kecamatan Besuki, Kabupaten Situbondo, dapat diklasifikasikan menjadi empat subsistem, di antaranya sebagai berikut. Register pengetahuan kelautan nelayan berkaitan dengan: (1) kondisi arus, (2) kondisi cuaca/iklim, (3) kondisi area penangkapan (fishing ground) dan tanda-tanda keberadaan ikan, serta (4) teknik dan alat tangkap yang digunakan. Berdasarkan hasil penelusuran dan pengkajian data yang telah dilakukan, masing-masing subsistem pengetahuan kelautan tersebut menimbulkan variasi bahasa sesuai dengan fungsi penggunaanya (register) dan saling bertautan satu sama lain. Tiap-tiap subsistem pengetahuan kelautan nelayan memiliki fungsi dan peran yang sangat penting terhadap keberhasilan dan keselamatan aktivitas penangkapan.

Register pengetahuan kelautan nelayan merupakan variasi bahasa berdasarkan penggunaan dan konteks dari penggunaannya yang mencerminkan proses sosial, dan mengandung makna kultural dan fungsional yang berbeda dengan jenis makna leksikal dan gramatikal. Dalam pandangan antropolinguistik, bahasa merupakan manifestasi konkret yang mengemban pemahaman-pemahaman kultural masyarakat penuturnya. Bahasa merupakan instrumen utama yang digunakan oleh masyarakat nelayan untuk membangun relasi sosial yang harmonis, dan sekaligus sebagai alat untuk mentransmisikan kebudayaannya agar tidak punah.

Variasi bahasa atau register bahasa nelayan merupakan representasi dari sistem pengetahuan kelautan masyarakat nelayan. Register-register tersebut sengaja diciptakan. 
Tujuannya adalah untuk melancarkan proses komunikatif dalam interaksi sosial masyarakat nelayan sebagai upaya untuk mempermudah akses dalam mengelola dan memanfaatkan sumberdaya laut. Secara linguistik, register tersebut memiliki fungsi komunikatif dan interaksional. Dalam penggunaan register kebahasaan tersebut terdapat nilai-nilai budaya yang positif, yang merupakan representasi dari sistem kognisi dan kearifan lokal masyarakat nelayan Madura di Desa Pesisir. Kearifan lokal yang dimaksud, berupa pengetahuanpengetahuan lokal tentang kelautan, pranata lokal, dan sistem normatif yang berlaku secara sosial di dalam kehidupan masyarakat nelayan. Secara sosiokultural, register pengetahuan kelautan nelayan menyimpan nilai-nilai lokal yang arif, yang mercerminkan identitas khas masyarkat maritim.

Bagi masyarakat nelayan, kebudayaan merupakan sistem gagasan atau sistem kognitif yang berfungsi sebagai pedoman hidup, referensi pola prilaku sosial, serta sebagai sarana untuk menginterpretasi dan memaknai berbagai peristiwa yang terjadi di lingkungannya. Pengetahuan kelautan nelayan merupakan wujud kebudayaan yang diwariskan secara turuntemurun, dimiliki bersama dan menjadi pengetahuan kolektif. Pengetahuan tersebut dipelajari dan diwariskan sebagai bentuk adaptasi terhadap lingkungan dalam rangka mempertahankan kelangsungan hidup masyarakat nelayan. Pola hidup masyarakat nelayan sepenuhnya bergantung pada sumberdaya laut. Pengetahuan dipelajari dan dikuasai, tujuannya adalah untuk mengarungi laut, menaklukkan medan, dan untuk mengelola dan memanfaatkan sumberdaya hayati laut.

Faktor ekologis, kedekatan hubungan antara masyarakat nelayan dengan laut (alam) telah melahirkan beragam jenis pengetahuan kelautan yang sedemikian rupa, yang digunakan sebagai fungsi adaptif dalam 'menaklukkan dan mengarungi laut' sebagai upaya untuk menjaga stabilitas kelangsungan hidup keluarganya. Suatu sistem pengetahuan yang telah mengantarkan corak sosial budaya masyarakat nelayan memiliki nilai budaya yang khas, yang berbeda dengan berbagai komunitas di sekitarnya.

\section{DAFTAR PUSTAKA}

Afrizal. 2015. Metode Penelitian Kualitatif: Sebuah Upaya Mendukung Penggunaan Penelitian Kualitatif dalam Berbagai Disiplin Ilmu. Jakarta: Raja Grafindo Persada.

Ahimsa-Putra, H. S. 1985. "Etnosains dan Etnometodologi: Sebuah Perbandingan”, Majalah Ilmu-ilmu Sosial Indonesia, 12(2):103-133.

Bogdan dan Taylor. 1975. Metode Penelitian Kualitatif. Bandung: Remaja Karya.

Chaer, A. 2007. Pengantar Semantik Bahasa Indonesia. Jakarta: Rineka Cipta.

Chaer, A. dan Agustina, L. 2010. Sosiolinguistik: Perkenalan Awal. Jakarta: Rineka Cipta.

Foley, W.A. 1997. Anthropological Linguistics: An Introduction. Oxford: Blackwell.

Halliday, M.A.K dan Hasan, R. 1994. Bahasa, Konteks, dan Teks: Aspek Bahasa dalam Pandangan Semiotik Sosial. Yogyakarta: Gadjah Mada University Press.

Kusnadi. 2009. "Kebudayaan Masyarakat Nelayan”, Makalah dalam kegiatan Jelajah Budaya, dengan tema "Ekspresi Budaya Masyarakat Nelayan di Pantai Utara Jawa", diselenggarakan oleh Balai Pelestarian Sejarah dan Nilai Tradisional, Kementerian Kebudayaan dan Pariwisata, di Yogyakarta 12-15 Juli 2010. 
Leech, G. 1981. Semantics. New Zealand: Penguin Books.

Pateda, M. 2001. Semantik Leksikal. Jakarta: Rineka Cipta

Pawitra, A. 2009. Kamus Lengkap Bahasa Madura Indonesia (dengan Ejaan Bahasa Madura Tepat Ucap). Jakarta: Dian Rakyat.

Ramlan, M. 2005. Ilmu Bahasa Indonesia: Sintaksis. Yogyakarta: CV Karyono.

Ricouer, P. 2015. Teori Interpretasi. Jogjakarta: IRCSoD.

Saussure, F.de. 1964. Course in General Linguistics. New York: Mc graw-Hill Book Company. Mouton.

Sibarani, R. 2015. "Pendekatan Antropolinguistik terhadap Kajian Tradisi Lisan", dalam Retrorika Majalah Ilmu Bahasa, 1(01):1-17.

Singgih, T.S. 2014. "Mengenal Sistem Pengetahuan, Teknologi, dan Ekonomi Nelayan Pantai Utara Jawa", dalam Agastya, 04(02):1-24.

Sofyan, A. 2016. Bahasa Madura. Yogyakarta: Jogja Bangkit Publisher.

Subroto, E.D. 2012.Pengantar Studi Semantik dan Pragmatik. Surakarta: Cakrawala Media.

Sudaryanto. 2015. Metode dan Teknik Analisis Bahasa, Pengantar Penelitian Wahana Kebudayaan Secara Linguistis. Yogyakarta: Universitas Sanata Dharma.

Wikipedia.org. 2003. Intangible Cultural Heritage UNESCO. 